\title{
Pengaruh Konseling Terhadap Pengetahuan dan Sikap Calon Akseptor KB dalam Pemilihan AKDR Post Plasenta
}

\author{
Novita Eka Kusuma Wardani ${ }^{1}$, Deasy Irawati ${ }^{2}$, Sri Wayanti ${ }^{2}$ \\ ${ }^{1}$ Prodi Kebidanan Bangkalan, Jurusan Kebidanan \\ ${ }^{2}$ Poltek Kesehatan Kementerian Kesehatan Surabaya ${ }^{3}$ \\ Email: novita.wardani2000@gmail.com
}

Naskah diterima 20 Desember 2019, Revisi 15 Januari 2019, Terbit 20 April 2019

\begin{abstract}
Abstrak
DOI: http://dx.doi.org/10.21107/pmt.v12i1.5172

Kontrasepsi pascapersalinan penting untung mencegah kehamilan yang tidak diinginkan. Dalam melayani kontrasepsi pasca salin, klien dan pasangannya harus mendapat informasi dari petugas kesehatan secara lengkap dan jelas agar dapat menentukan pilihannya dengan tepat. Penelitian ini merupakan penelitian kuasi eksperimental. Sampel yang digunakan dalam penelitian ini adalah seluruh wanita usia subur berusia 20 - 35 tahun yang tinggal di wilayah Puskesmas Kamal, Bangkalan. Hasil penelitian menunjukkan bahwa konseling bidan berpengaruh terhadap pengetahuan dan sikap ibu menjadi akseptor IUD post plasenta berdasarkan analisis statistik. Hasil statistik menunjukkan bahwa tingkat pengetahuan responden memilikiP value 0,014 pada kelompok perlakuan dan 0,025 . Sedangkan pada variabel sikap menunjukkan $P$ value 0,027 pada kelompok perlakuan dan 0,017 pada kelompok kontrol. Pemberian informasi dapat meningkatkan keberhasilan konseling sangat terkait dengan sikap/perilaku konselor dalam memberikan informasi Hasil analisis menunjukkan bahwa ada pengaruh yang signifikan antara pemberian konseling dengan tingkat pengetahuan dan sikap calon akseptor KB dalam pemilihan AKDR Post Plasenta
\end{abstract}

Kata kunci : Konseling, pengetahuan, sikap, AKDR post plasenta

\section{PENDAHULUAN}

Keluarga berencana merupakan upaya peningkatan kepedulian dan peran serta masyarakat melalui pendewasaan usia perkawinan, pengaturan, kelahiran, pembinaan ketahanan keluarga dan peningkatan kesejahteraan keluarga untuk mewujudkan keluarga kecil, bahagia dan sejahtera (Yuhedi dan Kurniawati, 2013).

Program Keluarga Berencana dirintis sejak tahun 1951 dan terus berkembang hingga tahun 1970 terbentuk Badan Koordinasi Keluarga Berencana (BKKBN). Program Keluarga Berencana bertujuan untuk menjarangkan kehamilan dengan menggunakan kontrasepsi. Metode kontrasepsi yang tersedia di Indonesia saat ini meliputi Metode Amenorea laktasi (MAL), Metode Keluarga Berencana Alamiah (KBA), Senggama Terputus, Metode Barier, Kontrasepsi Kombinasi, Kontrasepsi Progestin, Alat Kontrasepsi Dalam Rahim dan Kontrasepsi Mantap (Saifudin et.al, 2006). Partisipasi masyarakat dalam pemakaian kontrasepsi post plasenta didapatkan jumlah peserta
KB baru di Jawa timur tahun 2016 sebanyak 22.517 orang (12,24\%) dengan akseptor IUD, 13.564 orang (7,37\%) dengan akseptor implant dan 8.718 $(4,74 \%)$ dengan akseptor MOW (Dinkes Jatim, 2016).

Berdasarkan angka ketercapaian nasional dan kabupaten, jumlah akseptor AKDR post plasenta masih rendah. Pemasangan AKDR post plasenta relatif tidak sakit karena dipasang sesaat setelah plasenta lahir (Kemenkes, 2012). Grimes et.al, (2003) menyebutkan bahwa pemasangan AKDR segera setelah plasenta lahir aman dan efektif. Keuntungan langsung dari pemasangan yaitu memiliki motivasi yang tinggi, jaminan bahwa wanita tidak hamil, dan nyaman. Divakar et.al, (2013) menyatakan bahwa pemasangan AKDR CUT 380 A pada 10 menit setelah plasenta lahir adalah aman, nyaman, efektif biaya serta tingkat ekspulsi minimal jika dilakukan tenaga terlatih. Metode AKDR post plasenta efektif dalam menekan jumlah kelahiran dengan menurunkan unmeet 
need dan missed opportunity pada ibu pasca salin.

Mujiati (2013) mengemukakan bahwa dalam pelayanan KB pasca salin, sebelum mendapat pelayanan kontrasepsi, klien dan pasangannya harus mendapat informasi dari petugas kesehatan secara lengkap dan jelas agar dapat menentukan pilihannya dengan tepat. Pelayanan KB pasca persalinan akan berjalan dengan baik bila didahului dengan konseling yang baik, dimana klien berada dalam kondisi yang sehat, sadar, dan tidak di bawah tekanan ataupun tidak dalam keadaan kesakitan. Konseling pelayanan KB pasca persalinan dapat menggunakan media lembar balik Alat Bantu Pengambilan Keputusan (ABPK) ber-KB. Konseling KB pasca persalinan ini dapat dilaksanakan pada waktu pemeriksaan kehamilan, saat mengikuti kelas ibu hamil, selama proses persalinan, pasca persalinan, dan sebelum/sesudah pelayanan kontrasepsi. Setelah dilakukan konseling pada klien dan sudah ditentukan metode kontrasepsi yang dipilih, klien memberikan persetujuannya berupa tanda tangan pada lembar persetujuan tindakan medis (informed consent) untuk metode KB AKDR, implan serta kontrasepsi mantap (tubektomi dan vasektomi). Melakukan identifikasi potensi volume sampah.

Bidan merupakan tenaga kesehatan yang memiliki posisi yang strategis dalam meningkatkan kesejahteraan ibu, bayi, dan balita. Salah satu peran bidan adalah konseling. Bidan adalah ujung tombak pembangunan keluarga sejahtera dari sudut kesehatan dan pemberdayaan lainnya.Karena itu, sebagai ujung tombak dalam bidang kesehatan, bidan dituntut untuk berperan memberi pertolongan dini atau memberi petunjuk dalam pelayanan kesehatan (Suyono, 2007).

Diketahui dari 373 klinik di Indonesia, ternyata hanya 3 yang dapat dikategorikan memenuhi standar konseling. Salah satu indikator yang digunakan untuk mengukur standar itu adalah kecakapan konselor dalam melayani klien (Starh, 2002). Konseling hendaknya juga tidak berorientasi pada efisiensi yang lebih mempertimbangkan faktor waktu, tetapi lebih kepada keefektifan yang mengutamakan pencapaian keputusan terbaik (Zarfiel, 2002 ).

Berdasarkan studi pendahuluan yang telah dilakukan peneliti di Puskesmas Kamal, dari hasil wawancara langsung responden menyatakan bahwa kurang mengerti dengan AKDR post plasenta dan ada yang menyatakan kurang mengerti dengan kelebihan dan keterbatasan kontrasepsi AKDR post plasenta. Dari studi pendahuluan tersebut dapat diketahui bahwa bidan belum menjelaskan secara lengkap informasi saat konseling awal kontrasepsi AKDR. Tujuan penelitian ini yaitu untuk mengetahui pengaruh konseling terhadap pengetahuan dan sikap calon akseptor KB dalam Pemilihan Alat Kontrasepsi dalam Rahim Post Plasenta di Wilayah Puskesmas Kamal.

\section{METODOLOGI}

Jenis rancangan penelitian ini adalah kuasi eksperimental. Sampel yang digunakan dalam penelitian ini adalah seluruh wanita usia subur berusia 20 - 35 tahun yang tinggal di wilayah Puskesmas Kamal, Bangkalan. Pengambilan sampel dilakukan secara cluster sampling. Jumlah sampel dalam penelitian ini adalah 50 orang dengan pembagian 25 orang sebagai kelompok kontrol dan 25 orang sebagai kelompok perlakuan. Kelompok kontrol diberi leaflet saja, kelompok perlakuan diberi leaflet, penjelasan dan konseling.Variabel pengetahuan dan sikap diukur sebelum dan sesudah perlakuan dengan alat ukur checklist. Waktu penelitian dilakukan tanggal 1 Februari-30 Maret 2018. Uji statistik yang digunakan adalah Wilcoxon Sign Rank.

\section{HASIL DAN PEMBAHASAN}

Karakteristik responden dalam penelitian ini digambarkan berdasarkan pendidikan, umur dan jumlah paritas. Data responden berdasarkan pendidikan, umur dan jumlah paritas dijelaskan pada Tabel 1 dibawah ini.

Tabel 1. Karakteristik Responden Berdasarkan pendidikan, umur, dan jumlah paritas

\begin{tabular}{lcc}
\hline $\begin{array}{l}\text { Karakteristik } \\
\text { Responden }\end{array}$ & Frekuensi & $\%$ \\
\hline SD & 2 & 4 \\
\hline
\end{tabular}




\begin{tabular}{lcc}
\hline $\begin{array}{l}\text { Karakteristik } \\
\text { Responden }\end{array}$ & Frekuensi & $\%$ \\
\hline SMP & 14 & 28 \\
\hline SMA & 31 & 62 \\
\hline D3 & 3 & 6 \\
\hline TOTAL & 50 & 100 \\
\hline$<20 \quad$ Tahun & 3 & 6 \\
\hline $21-35$ Tahun & 27 & 54 \\
\hline$>35 \quad$ Tahun & 20 & 40 \\
\hline TOTAL & 50 & 100 \\
\hline Primipara & 21 & 42 \\
\hline Multipara & 29 & 58 \\
\hline TOTAL & 50 & 100 \\
\hline
\end{tabular}

Berdasarkan hasil karakteristik responden diatas, pendidikan responden paling banyak adalah SMA yaitu 31 responden (62\%). Pendidikan memberikan informasi secara akurat, benar dan dapat dipertanggungjawabkan secara ilmiah. Pendidikan memberikan akses informasi dan pengetahuan yang dibutuhkan oleh manusia. Pendidikan merupakan jembatan awal seorang ibu dalam mengenal segala hal yang baru dalam kehidupannya. Dengan demikian semakin tinggi pendidikan seorang wanita, maka hal yang diketahuinya pun akan bertambah. Pendidikan mempengaruhi proses belajar, makin tinggi pendidikan seseorang makin mudah wanita tersebut untuk menerima informasi. Dengan pendidikan tinggi maka seorang wanita akan cenderung untuk mendapatkan informasi, baik dari orang lain maupun dari media massa (Widayatun, 2004). Seorang wanita dengan pendidikan tinggi memiliki akses informasi yang lebih luas dan banyak. Wanita dengan pendidikan rendah, cenderung memiliki pengetahuan dan informasi terbatas (Widayatun, 2004).

Umur responden yang terbanyak adalah usia 21-35 tahun yaitu 27 orang (54\%). Jumlah paritas responden yang terbanyak adalah multipara yaitu 29 orang (58\%). Menurut Notoatmodjo (2003) mengatakan bahwa usia merupakan variabel yang selalu diperhatikan dalam penelitian-penelitian epidemiologi yang merupakan salah satu hal yang mempengaruhi pengetahuan. usia adalah lamanya waktu hidup

Seseorang dalam tahun yang dihitung sejak dilahirkan sampai berulang tahun yang terakhir. Singgih (1998), mengemukakan bahwa makin tua usia seseorang maka proses-proses perkembangan mentalnya bertambah baik, akan tetapi pada usia tertentu, bertambahnya proses perkembangan mental ini tidak secepat seperti ketika berusia belasan tahun. Selain itu Abu Ahmadi (2001), juga mengemukakan bahwa memang daya ingat seseorang itu salah satunya dipengaruhi oleh usia. Dari uraian ini maka dapat kita simpulkan bahwa bertambahnya usia seseorang dapat berpengaruh pada pertambahan pengetahuan yang diperolehnya, akan tetapi pada usia-usia tertentu atau menjelang usia lanjut kemampuan penerimaan atau mengingat suatu pengetahuan akan berkurang.

Tabel 2. Tingkat Pengetahuan responden tentang Pemilihan AKDR Post Plasenta di Wilayah Puskesmas Kamal

\begin{tabular}{|c|c|c|c|c|}
\hline \multirow{2}{*}{$\begin{array}{c}\text { Tingkat } \\
\text { Pengetahuan } \\
\text { Responden }\end{array}$} & \multicolumn{2}{|c|}{ Perlakuan } & \multicolumn{2}{|c|}{ Kontrol } \\
\hline & $\begin{array}{c}\text { Awal } \\
n \\
(\%)\end{array}$ & $\begin{array}{c}\text { Akhir } \\
n \\
(\%)\end{array}$ & $\begin{array}{c}\text { Awal } \\
n \\
(\%)\end{array}$ & $\begin{array}{c}\text { Akhir } \\
n \\
(\%)\end{array}$ \\
\hline Kurang & $9(36)$ & $3(12)$ & $7(28)$ & $6(24)$ \\
\hline Cukup & 8 (32) & $6(24)$ & $5(20)$ & $6(24)$ \\
\hline Baik & $3(20)$ & $12(48)$ & 3 (12) & 3 (12) \\
\hline Total & 25 & 25 & 25 & 25 \\
\hline$P$ value & 0,014 & $\begin{array}{l}(100) \\
0,025\end{array}$ & & \\
\hline
\end{tabular}

Tabel 3. Sikap responden terhadap pemilihan AKDR post plasentadi wilayah Puskesmas Kamal

\begin{tabular}{lcccc}
\hline & \multicolumn{2}{c}{ Perlakuan } & \multicolumn{2}{c}{ Kontrol } \\
Sikap & Awal & Akhir & Awal & Akhir \\
& $\mathrm{n}$ & $\mathrm{n}$ & $\mathrm{n}$ & $\mathrm{n}$ \\
& $(\%)$ & $(\%)$ & $(\%)$ & $(\%)$ \\
\hline Baik & $12(48)$ & $13(52)$ & $13(52)$ & $15(60)$ \\
Kurang & $13(52)$ & $12(48)$ & $12(48)$ & $10(40)$ \\
Total & $25(100)$ & $25(100)$ & $25(100)$ & 25 \\
P value & 0,027 & 0,017 & & $(100)$ \\
\hline
\end{tabular}

Hasil penelitian menunjukkan bahwa konseling bidan berpengaruh terhadappengetahuan dan sikap ibu menjadi akseptor IUD post plasenta berdasarkan analisis statistik. Hasil statistik pada tabel 2 menunjukkan bahwa tingkat pengetahuan responden memiliki $P$ value 0,014 pada kelompok perlakuan dan 0,025 pada kelompok kontrol, sehingga dapat disimpulkan bahwa ada pengaruh yang signifikan antara pemberian konseling dengan tingkat pengetahuan responden tentang pemililhan AKDR post plasenta. 
Pengetahuan merupakan hasil dari tahu dan ini terjadi setelah orang melakukan penginderaan terhadap obyek tertentu. Penginderaan terhadap obyek terjadi melalui panca indera manusia,yakni: penglihatan, pendengaran, penciuman, rasa dan raba. Sebagian besar pengetahuan manusia diperoleh melalui mata dan telinga (Notoadmodjo, 2007). Informasi merupakan satu bagian dari pelayanan yang sangat berpengaruh bagi calon akseptor maupun akseptor pengguna mengetahui apakah kontrasepsi yang dipilih telah sesuai dengan kondisi kesehatan dan sesuai dengan tujuan akseptor dalam memakai kontrasepsi tersebut. Informasi sangat menentukan pemilihan kontrasepsi yang dipilih, sehingga informasi yang lengkap mengenai kontrasepsi sangat diperlukan guna memutuskan pilihan metode kontrasepsi yang akan dicapai.

Pada tabel 3 menunjukkan $P$ value 0,027 pada kelompok perlakuan dan 0,017 pada kelompok kontrol. Hal ini menunjukkan ada pengaruh signifikan antara pemberian konseling dengan sikap responden dalam memilih AKDR post plasenta. Sikap merupakan reaksi atau respon seseorang yang masih tertutup terhadap suatu stimulus atau obyek (Notoadmodjo,2007.). Willis (2009) mengemukakan bahwa keberhasilan konseling sangat terkait dengan sikap/perilaku konselor dalam memberikan informasi seperti; memiliki rasa empati,kehangatan,penghargaan positif (respek), pengendalian kecemasan, dan pola komunikasi. Azwar (2005) mengemukakan faktor-faktor pembentuk sikap adalah kebudayaan, orang lain yang dianggap penting, media massa, institusi, atau lembaga pendidikan, pengalaman pribadi, dan faktor emosi dalam diri individu. Sedangkan Niven (2002) lewat pendekatan pembelajaran sosial menyebutkan bahwa pembentukan atau perubahan sikap orang dewasa terjadi melalui "terpaparnya" cara baru untuk melakukan suatu kegiatan melalui tindakan yang dilakukan oleh kawan, rekan, kerja, orang tua, atau saudara.

\section{KESIMPULAN}

Kesimpulan dalam penelitian ini adalah Konseling dapat meningkatkan Pengetahuan dan Sikap Calon Akseptor KB dalam Pemilihan Alat Kontrasepsi dalam Rahim Post Plasenta.

\section{DAFTAR PUSTAKA}

Azwar, 2005. Sikap Manusia: Teori dan Pengukurannya. Yogyakarta Pustaka Pelajar.

Grimes, Schulz, Van Vliet, Stanwood. 2003 Immediate Post Partum Insertion Of intrauterine Devices. Cochrane Database Syst Rev. 2003 (1) : CD 003036.

Mujiati, Inti. 2013. Pelayanan Kb Pasca Persalinan dalam Upaya Mendukung Percepatan Penurunan Angka Kematian Ibu. Buletin Jendela Data dan Informasi Kesehatan. 2 (2013) : 11-16.

Niven, Neil. 2002. Psikologi Kesehatan Keperawatan Pengantar untuk Perawat dan Profesional Kesehatan lain. Jakarta : EGC

Notoatmodjo. 2007. Promosi Kesehatan dan Ilmu Perilaku. Jakarta : Rineka Cipta.

Starh. 2002. Konseling KB Berkualitas Belum Dipahami. Available from : http: //sidrap-file/2012/01/konseling $\mathrm{KB}$ berkualitas belum dipahami.

Saifuddin $A B$, Affandi B, Baharuddin $M$, Soekir S, editor. Buku Panduan Praktis Pelayanan Kontrasepsi. Jakarta : Yayasan Bina Pustaka Sarwono Prawirohardjo; 2006.

Suyono, H. 2007. Bidan mandiri sebagai ujung tombak Posyandu. http://www.damandiri.or.id. Diakses 20 Januari 2018. 
Wardani, N. E. K, Irawati, D \& Wayanti, S Pengaruh Konseling 5 